TUGAS BIMBINGAN DAN KONSELING

“ PENDEKATAN DAN MODEL PELAYANAN BK POLA 17 PLUS JENIS LAYANAN ( LANJUTAN ) “

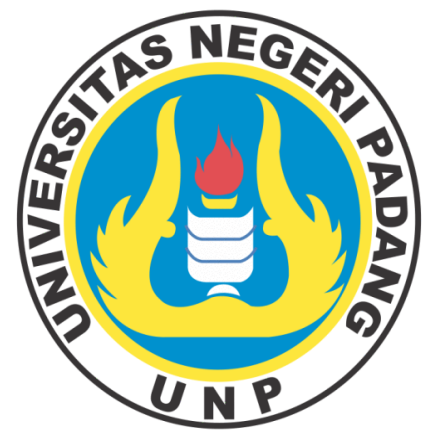

DOSEN PEMBIMBING :

Dr. Yeni Karneli, M.Pd, Kons

DISUSUN OLEH :

TESYA NANDA RAHAYU

19332010

PENDIDIKAN TARI

UNIVERSITAS NEGERI PADANG

2021 


\title{
PENDEKATAN DAN MODEL PELAYANAN BK POLA 17 PLUS “JENIS LAYANAN LANJUTAN"
}

\author{
Tesya Nanda Rahayu \\ Jurusan sendratasik \\ Universitas Negeri Padang
}

\begin{abstract}
BK Pola-17 Plus is a task area for school counselors in counseling services. One type of service at BK Pola-17 Plus is consulting services. Consultation services in BK Pola-17 Plus are a development of services at BK Pattern 17. Consultation services are new to BK in schools, especially for school counselors. For this reason, counselors need a deep understanding of consulting services in order to achieve successful service delivery.

Pendahuluan

Bimbingan dapat diartikan sebagai sesuatu proses pemberian bantuan kepada individu yang dilakukan secara berkesinambungan, supaya individu tersebut dapat memahami dirinya sendiri, sehingga dia sanggup mengarahkan dirinya dan dapat bertindak secara wajar, sesuai dengan tuntutan dan keadaaan lingkungan sekolah, keluarga, masyarakat dan kehidupan pada umumnya, Bimbingan membantu individu mencapai perkembangan diri secara optimal sebagai makhluk sosial.

Konseling merupakan suatu upaya bantuan yang dilakukan dengan empat mata atau tatap muka antara konselor, dan konseli yang berisi usaha yang selaras, unik, human (manusiawi), yang dilakukan dalam suasana keahlian dan yang didasarkan atas norma-norma yang berlaku, agar konseli memperoleh konsep diri dan kepercayaan diri sendiri dalam memperbaiki tingkah lakunya saat ini dan mungkin pada masa yang akan datang.
\end{abstract}


Secara umum tujuan pelaksanaan layanan bimbingan dan konseling adalah berupaya membantu siswa menemukan pribadinya, dalam hal mengenal kekuatan dan kelemahan dirinya, serta menerima dirinya secara positif dan dinamis sebagai modal pengembangan diri lebih lanjut.

a. Bimbingan Kelompok

Bimbingan kelompok adalah Suatu kegiatan kelompok yang dilakukan oleh sekelompok orang dengan memanfaatkan dinamika kelompok yaitu adanya interaksi saling mengeluarkan pendapat, memberikan tanggapan, saran, dan sebagainya, dimana pemimpin kelompok menyediakan informasi-informasi yang bermanfaat agar dapat membantu individu mencapai perkembangan yang optimal.

Layanan bimbingan kelompok merupakan media pengembangan diri untuk dapat berlatih berbicara, menanggapi, memberi menerima pendapat orang lain, membina sikap dan perilaku yang normatif serta aspek-aspek positif lainnya yang pada gilirannya individu dapat mengembangkan potensi diri serta dapat meningkatkan perilaku komunikasi antar pribadi yang dimiliki.

b. Konseling Kelompok

Layanan konseling kelompok, yaitu layanan bimbingan dan konseling yang memungkinkan peserta didik (konseli) memperoleh kesempatan untuk pembahasan dan pengentasana permasalahan yang dialaminya melalui dinamika kelompok. Masalah yang dibahas merupakan masalah-masalah pribadi yang dialami oleh masing-masing anggota kelompok.

Konseling kelompok memfokuskan diri pada proses interpersonal dan strategi penyelesaian masalah yang berkaitan dengan pemikiran, perasaan, dan perilaku yang disadari. Metode yang digunakan adalah dukungan dan umpan balik (feedback) interaktif dalam sebuah kerangka berpikir saat itu juga.

Proses pelaksanaan konseling kelompok dilaksanakan melalui tahap-tahap berikut:

- Tahap pembentukan

- Tahap peralihan

- Tahap kegiatan

- Tahap pengakhiran.

c. Konsultasi

Konsultasi adalah layanan konseling ynag dilaksanakan oleh konselor terhadap seorang pelanggan di sebut konsulti yang memungkinkan konsulti memperoleh wawasan, pemahaman dan cara-cara yang perlu dilaksanakannya dalam menangani kondisi dan/atau permasalahan pihak ketiga. konsultasi pada dasarnya dilaksanakan secara perorangan dalam format tatap muka antara konsultan dan konsulti.

Layanan konsultasi bertujuan agar konsulti dengan kemampuannya sendiri dapat menangani kondisi dan /alat permasalahan yang dialami pihak ketiga.

d. Mediasi

Layanan mediasi, yaitu layanan bimbingan dan konseling yang dilaksanakan konselor (guru) terhadap dua orang atau lebih yang sedang dalam keadaan saling tidak menemukan kecocokan. 
Layanan mediasi pada umumnya bertujuan agar tercapai kondisi hubungan yang positif dan kondusif diantara klien, yaitu pihak-pihak yang berselisih.

e. Advokasi

Advokasi adalah layanan bimbingan dan konseling yang membantu konseli untuk memperoleh kembali hak-hak dirinya yang tidak diperhatikan dan/atau mendapat perlakuan yang menyalahi hak-haknya.

Layanan advokasi dalam konseling bermaksud mengentaskan klien dari suasana yang menghimpit dirinya karena hak-hak yang hendak dilaksanakan terhambat dan terkekang sehingga keberadaan, kehidupan dan perkembangannya, khususnya dalam bidang pendidikan menjadi tidak lancar, terganggu atau bahkan terhenti atau terputus.

\section{DAFTAR PUSTAKA}

https://calongurubk.blogspot.com/2017/03/jenis-jenis-layanan-bimbingan-dan.html

Wingkel, W.S. dan M. M. Srihastuti. 2007. Bimbingan dan Konseling di Institusi Pendidikan. Yogyakarta. Media Abadi

Prayitno. 1995. "Layanan Bimbingan dan Konseling Kelompok (Dasar dan Profil)" Jakarta: Ghalia Indonesia.

https://calongurubk.blogspot.com/2017/03/jenis-jenis-layanan-bimbingan-dan.html 